\title{
Effect of Three Storage Methods on the Quality and Shelf-Life of White Yam (Dioscorea rotundata) Cultivars Pona and Tela
}

\author{
Bonaventure Kissinger Maalekuu ${ }^{1}$, Joseph Kofi Saajah ${ }^{2} \&$ Alphones Kwasi Addae ${ }^{3}$ \\ ${ }^{1}$ Department of Horticulture, Kwame Nkrumah University of Science and Technology, Kumasi, Ghana \\ ${ }^{2}$ Newmont Mining Cooperation, Golden Ridge Resources Ltd, New Abirem, Ghana \\ ${ }^{3}$ Department of Agricultural Science, Presbyterian Senior High School, Berekum, Ghana \\ Correspondence: Bonaventure Kissinger Maalekuu, Department of Horticulture, Kwame Nkrumah University of \\ Science and Technology, Kumasi, Ghana. Tel: 233-209-065-357. E-mail: kbmaalekuu.agric@knust.edu.gh \\ Joseph Kofi Saajah, Newmont Mining Cooperation, Golden Ridge Resources Ltd, New Abirem, Ghana. Tel: \\ 233-203-814-890. E-mail: jksaajah@yahoo.com
}

Received: April 15, 2014 Accepted: May 19, 2014 Online Published: June 15, 2014

doi:10.5539/jas.v6n7p221 URL: http://dx.doi.org/10.5539/jas.v6n7p221

\begin{abstract}
Postharvest losses especially at storage are a major challenge in yam production. Hence, the study was aimed to investigate and find out the suitable storage method which would minimize losses incurred during storage. A survey was conducted to assess the pre-storage treatments applied to yam, methods adopted for storage and farmers knowledge on postharvest losses. Effect of storage methods on major factors that initiate and cause losses and proximate analysis to determine the nutritional variation of White yam cultivars, Pona and Tela were also conducted before and after storage. The survey revealed, only few farmers (28\%) apply agro-chemicals to their harvested tubers before storage. The most common storage method used by the respondents is the yam barn (60\%). Burial $(30 \%)$ and heaps on floor (10\%) storage methods were also used depending on time of harvest. The respondents also estimated $4-40 \%$ as losses often incurred after harvest and in storage due to injuries (31\%), pests (23\%), weight loss (4\%), sprout (21\%) and decay (40\%). The storage experiment conducted however showed sprouting at storage as the major cause of loss $(93 \%)$. The storage methods caused a significant reduction on the nutritional composition of the stored tubers. With the three storage methods (heaps on floor, yam barn and open sided) evaluated, the open sided storage performed best in respect to weight loss, sprouting, decay, pest damage and nutritional composition.
\end{abstract}

Keywords: proximate, sprouting, nutritional, tubers, shelf-life, qualities, interactions

\section{Introduction}

Yams are among the most important staple food crops in the world particularly in the tropical and sub-tropical countries (Okigbo \& Ogbonnaya, 2006). In fact, yam plays a central role in the food economy in most West African Countries especially Ghana. Yam is a major source of energy in the daily diet of many people in Ghana. Yam contributes more than 200 calories per person per day for more than 150 million people in West Africa (FAO, 2005). Although yam tubers are mostly used for their high content of carbohydrate, they also have high protein, minerals such as calcium, phosphorus, iron and vitamins B and C (Splittstoeser \& Rhodes, 1973). The crop without any doubt contributes importantly to food security and poverty reduction in Ghana since it can be stored relatively better than many tropical crops.

Aside their high values as a food source, some species of yam have been used medicinally to treat diseases like diabetes, heart disorder and preventing hypercholemia (Undie \& Akabue, 1986).

Yams are highly regarded and are thus closely integrated into the social, cultural, economic and religious aspects of life in some production areas. The traditional ceremonies such as Homowo, Hogbetsotso, Apour are new yam festivals in Ghana that accompany yam production that depicts a high status given to the crop.

Yam is an extremely vital crop both in the domestic and international market. In fact, Ghana is the third largest producer of yam in the world following Nigeria and Cote d'Ivoire however the largest exporter annually (FAO, 2005). 
The storage of yam is challenged by numerous problems and often beyond the usual farmer's control. Postharvest losses constitute a major problem and has been estimated by various authorities that $20-80 \%$ of harvested yams are lost after harvest. According to the National Academy of Sciences (NAS) (1978), estimate of losses are ranging between $40-80 \%$ and sometimes as high as $100 \%$ for certain crops in the tropics and subtropics where temperatures are extremely high. FAO (1998) estimated that an average of over $25 \%$ of the yams produced and harvested in Nigeria are lost in storage.

It is obvious that the cost of preventing food losses is generally less than producing an additional amount of food crop of the same value and quantity. It is also generally believed that reducing postharvest losses would be the next most effective tool for preventing global food shortage.

The major task therefore was to find a suitable and cost effective storage method or technology to keep the excess harvest and make the crop available round the year. The study hence aimed to focus on better storage conditions which extend and maintain the edible and marketable qualities and shelf-life of some white yam cultivars.

\section{Material and Methods}

\subsection{Survey}

A survey was conducted in five communities: Hani, Nkyeraa, Nsawkaw, Seikwa and Subinso in two major yam growing districts: Wenchi and Tain of BrongAhafo region in Ghana to find out; pre-storage treatments applied to yam by farmers, methods adopted by farmers for the storage of yam and farmers' knowledge on postharvest losses during storage. Simple random sampling procedure was used to select fifty respondents each from the five yam producing communities for interview. The interview was conducted by the researcher using structured questionnaires. The data collected was analysed using Statistical Package for Social Sciences (SPSS) - descriptive and inferential statistics.

\subsection{Experimental Work}

The experiment was executed between November $3^{\text {rd }} 2012$ and March $30^{\text {th }} 2013$ having the period of 150 days Storage structures used for the study: The Traditional barn, Heaps on floor covered with litter and open-sided shelves store with rodent guards were prepared prior to the commencement of the Research work. The structures were erected in open air, where sufficient shade and ventilation were available.

\subsection{Parameters}

Factors such as weight loss, decay, sprout and pest damage that initiate and cause loss at storage were studied.

The weight of the yam tubers were measured and recorded at fortnight interval using electronic balanced. Weight loss of yam tubers were computed and expressed in percentage.

Decayed, sprouted and pest damaged yam tubers, were assessed through visual observation at fortnight interval during the experimental period. The data for sprouted and pest damaged yam tubers were counted, recorded and expressed in percentages respectively.

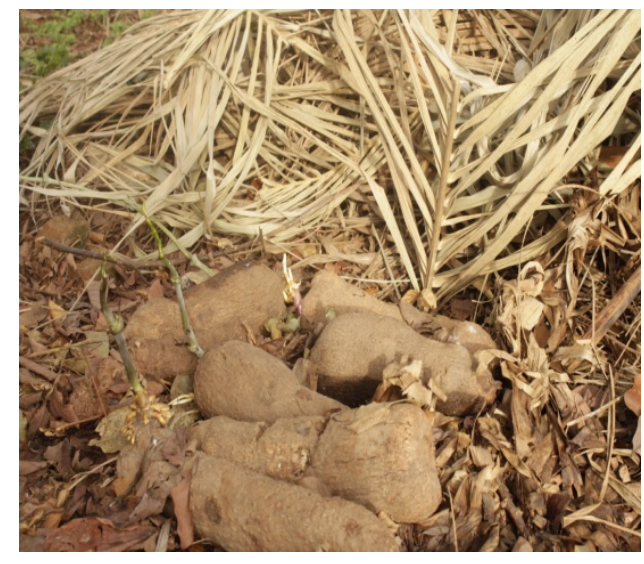

Figure 1. Heap on floor storage

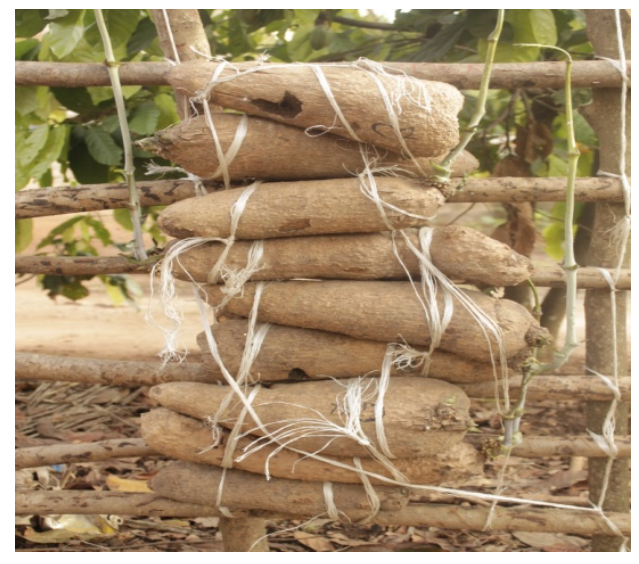

Figure 2. Traditional barn 

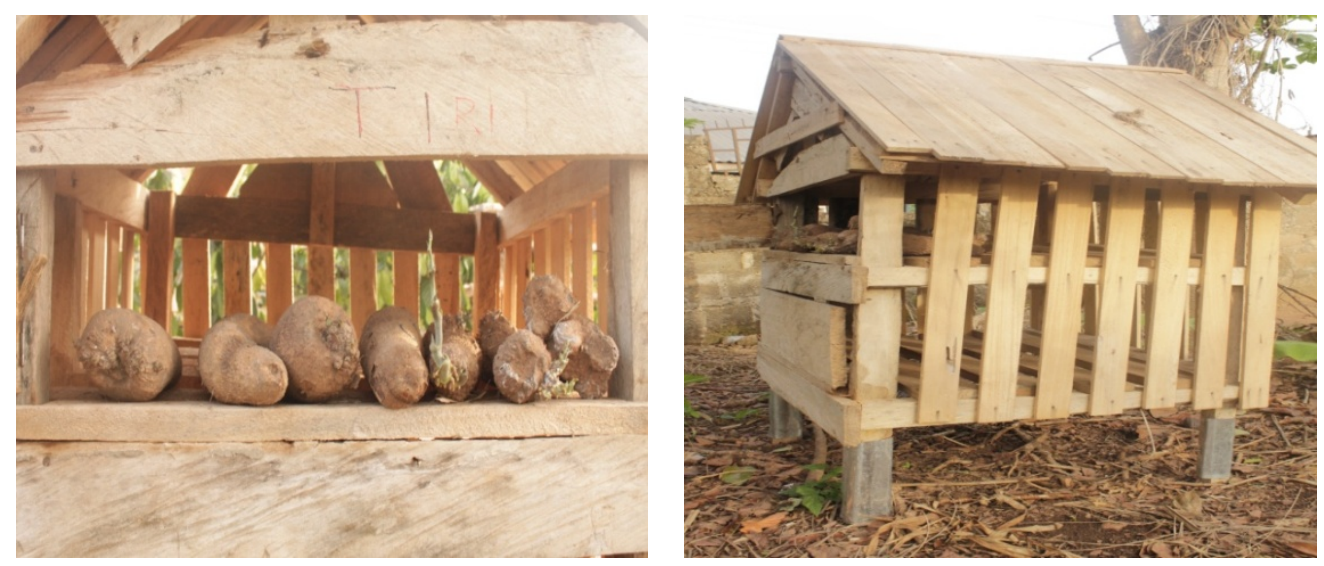

Figure 3. Open sided storage structure

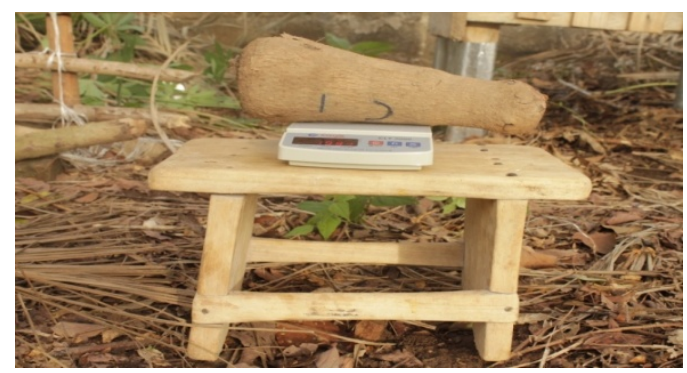

Figure 4. Weighing of tubers

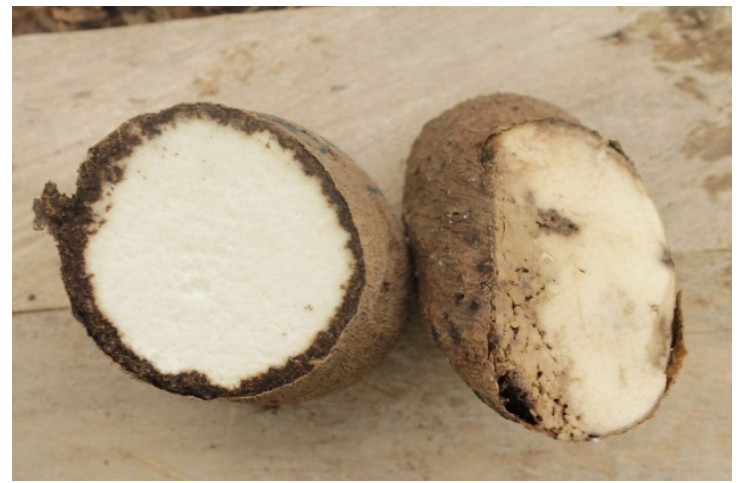

Figure 6. Tubers showing rot

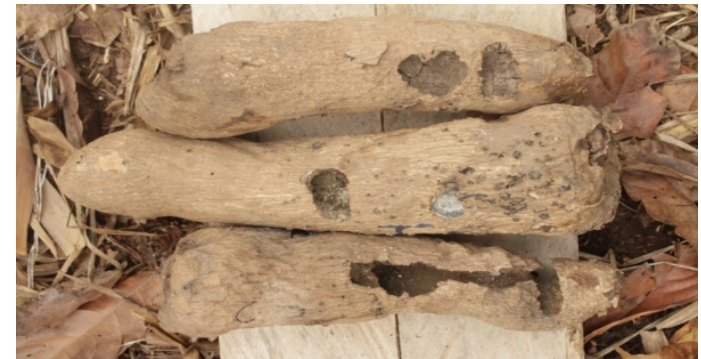

Figure 5. Tubers of yam damaged by pests

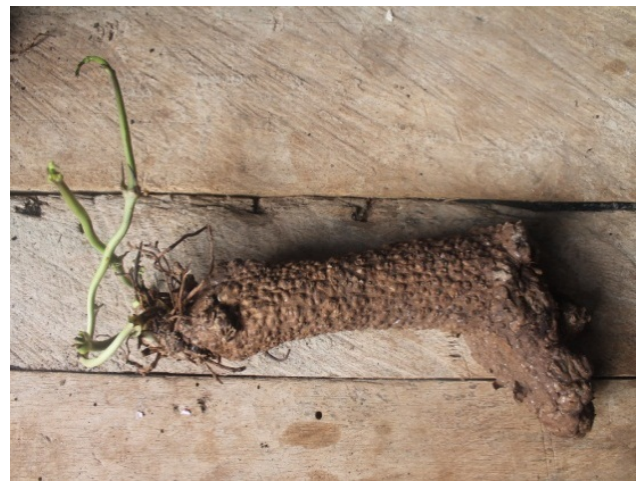

Figure 7. A tuber of sprouted yam

\subsection{Proximate Analysis}

Proximate analysis was conducted on the stored yam tubers at the beginning of experiment and at the end of the study to establish the effect the various storage methods on the Crude Fibre, Crude Protein, Ash, Carbohydrate and Moisture Content.

\subsection{Data Analysis}

Data collected from the studied parameters were subjected to analysis of variance using Statistix Student 9.0 and means were compared at least significant differences (Lsd) of 1 and 5 per cent. Count and percentage data were transformed using square root transformation. 


\section{Results and Discussion}

\subsection{Field Survey}

\subsubsection{Postharvest Activities}

Sixty percent (60\%) partly sell and store their yam while $40 \%$ solely store immediately after harvest. A relatively low number of the producers apply agro-chemicals on yams as postharvest treatment before storage. Among the all the farmers interviewed only twenty eight per cent (28\%) apply agrochemicals on yam tubers while the majority (72\%) of them do not use pre-treatment application before storing.

Majority of them (68\%) estimated the storage life of yam to be 150 days (5 months).

Three storage methods; storage in traditional yam barns, burial storage method and heaps on floor were identified and used by the respondents for storing their harvested yams. The commonly used one is the yam barns and the least preferred is by the heaps on floor storage technique.

\subsubsection{Postharvest Losses}

The farmers (respondents) reported that, the postharvest losses incurred at transit and storage ranged between $1-30 \%$. Forty (40) per cent of farmers reported $11-20 \%$ losses while majority $(56 \%)$ of the producers reported a postharvest loss within a range of $1-10 \%$ and a few (4\%) suffered a high loss of $21-30 \%$ (Figure $3-1$ ).

They attributed the losses on their harvested produce to a number of contributing factors namely decay ( $40 \%)$, injuries (31.3\%), pests (22.6\%), weight loss (4.3\%) and sprout (1.7\%) (Figure 3-2).

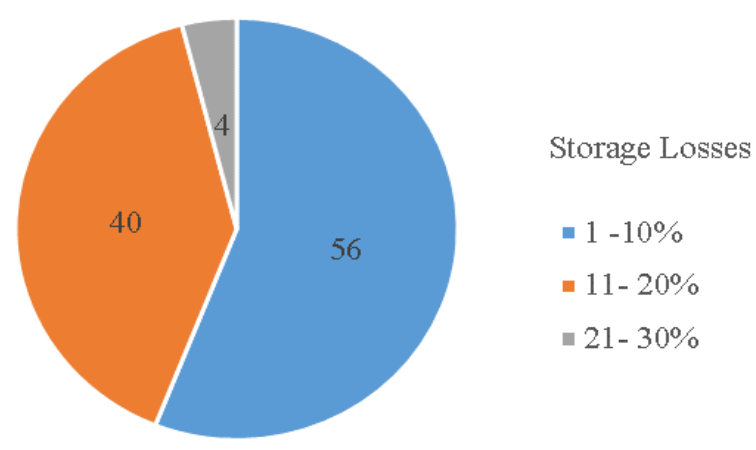

Figure 8. Percentage Losses at Storage

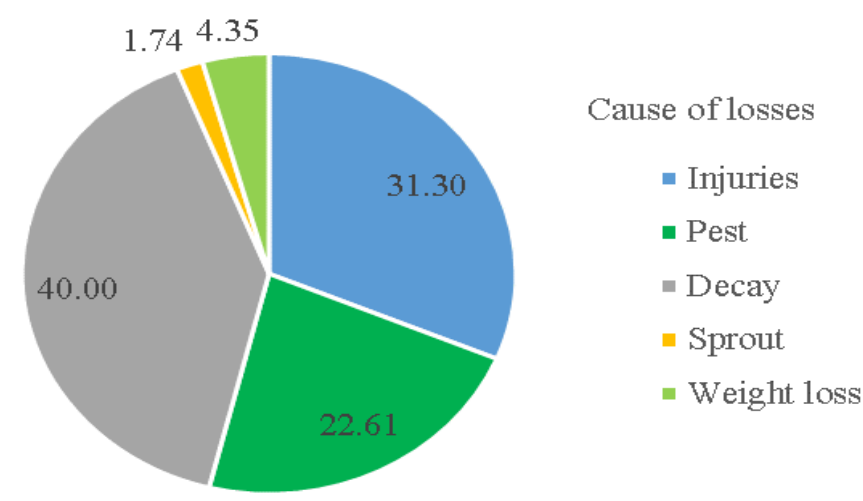

Figure 9. Farmers' knowledge on the causes of Losses

\subsubsection{Control Measures}

Yam producers interviewed gave the account that, losses could be prevented or minimized by careful handling of harvested tubers during harvesting and transporting, use of pesticides, clearing of bushes and traps (used to deter 
pests and rodents). They also believed that, decay and weight loss could be minimized by preventing injuries to tubers and shading respectively.

\subsection{Storage Experiment}

Three storage methods were evaluated to find out their effect on the quality and shelf-life of the White yam. Factors (decay, pests/rodents and weight loss) identified by respondents as the major causes of postharvest loss and sprout were studied and reported on.

Table 1. Effect of cultivar variation on pest damage, weight loss and sprout of White yam

\begin{tabular}{llll}
\hline Cultivar & Pests Attack & Weight Loss & Sprout \\
\hline Pona & $28.89 \mathrm{a}$ & $21.12 \mathrm{~b}$ & $55.56 \mathrm{~b}$ \\
Tela & $0.00 \mathrm{~b}$ & $25.95 \mathrm{a}$ & $77.78 \mathrm{a}$ \\
Lsd (0.05) & 7.34 & 5.7 & 19.93 \\
CV & 48.41 & 18.82 & 28.46 \\
\hline
\end{tabular}

Table 2. Effect of storage methods on pest damage, weight loss and sprout of White yam

\begin{tabular}{llll}
\hline Storage Methods & Pests Attack & Weight Loss & Sprout \\
\hline Open sided & $0.00 \mathrm{c}$ & $25.40 \mathrm{a}$ & $60.00 \mathrm{a}$ \\
Traditional Barn & $16.67 \mathrm{~b}$ & $22.36 \mathrm{a}$ & $73.33 \mathrm{a}$ \\
Heap on floor & $26.67 \mathrm{a}$ & $22.84 \mathrm{a}$ & $66.67 \mathrm{a}$ \\
Lsd & 7.34 & 5.7 & 19.93 \\
CV & 48.41 & 18.82 & 28.46 \\
\hline
\end{tabular}

Table 3. Effect of cultivar and storage method on pest damage, weight loss and sprout of White yam

\begin{tabular}{llll}
\hline Interactions & Pests Attack & Weight Loss & Sprout \\
\hline Pona *Open sided & $0.00 \mathrm{c}$ & $22.84 \mathrm{a}$ & $53.33 \mathrm{~b}$ \\
Tela *Open sided & $0.00 \mathrm{c}$ & $27.96 \mathrm{a}$ & $66.67 \mathrm{ab}$ \\
Pona *Traditional Barn & $33.33 \mathrm{~b}$ & $19.94 \mathrm{a}$ & $53.33 \mathrm{~b}$ \\
Tela *Traditional Barn & $0.00 \mathrm{c}$ & $24.79 \mathrm{a}$ & $93.33 \mathrm{a}$ \\
Pona* Heap & $53.33 \mathrm{a}$ & $20.58 \mathrm{a}$ & $60.00 \mathrm{ab}$ \\
Tela *Heap & $0.00 \mathrm{c}$ & $25.09 \mathrm{a}$ & $73.33 \mathrm{ab}$ \\
Lsd & 8.99 & 4.65 & 24.41 \\
CV & 48.41 & 18.82 & 28.46 \\
\hline
\end{tabular}

\subsubsection{Pest Damage}

The results depicted in the above Tables revealed the resistibility of Tela cultivar $(0.00 \%)$ to pests/rodents attack throughout the storage period with all storage methods employed for the studies and was significantly different $(\mathrm{p}<0.05)$ from Pona $(28.89 \%)$ which was prone to pest or rodent attack. This resistivity could be as result of genetic quality of this particular cultivar of the white yam. Pona on the other hand, was prone to pests and rodent attack when heaped on the floor (53.33\%) and stored in the traditional yam barns (33.33\%). According to Igbeka (1985), rodent pests frequently attack and feed on some of the harvested tubers stored in yam barns. The easy accessibility of the stored tubers to the rodent and pests on floor caused the occurrence of high percentage of the attacked tubers. However, open sided storage method was able to put the pests and rodents into completely checked as it recorded $0.00 \%$ pest attack. The traditional barn storage method was significantly better $(\mathrm{p}<0.05)$ than the heap on floor storage method which had the highest level of pest attack.

\subsubsection{Weight Loss}

A significant difference $(\mathrm{p}<0.05)$ was recorded between the cultivars of Pona and Tela where both had $21.12 \%$ and $25.95 \%$ weight loss respectively. Thus, Tela was more prone to weight loss. The storage methods showed no 
significant effect $(\mathrm{p}>0.05)$ in reducing weight loss, as they performed statistically equal in minimizing the weight loss among the stored tubers.

Weight loss is one of the most severe indications of yam tuber deterioration which may be due to deleterious reactions (Osuji \& Umezurike, 1985). This is often due to excessive respiration (largely due to the oxidation of stored starch) of stored produces occurring as a result of persistent high temperatures and hence, account for postharvest loss. It is positively correlated with loss of water or moisture within a produce as a result of transpiration. The respiration, transpiration and sprouting are the factors responsible for weight loss.

These processes in effect, influence the appearance and cause tubers to shrivel. Weight loss also affected the quality of the produce (yam tubers at storage), as often seen in fruits and leafy vegetables (Ikediobi \& Oti, 1983).

\subsubsection{Sprouting}

Both the cultivars recorded a significant difference $(p<0.05)$ against each other. Tela significantly recorded the highest number of sprout compared to Pona. The result revealed that sprouting is the major factor that contribute and account for losses of yam tubers at storage. Generally, sprouting was significantly high at storage and all the storage methods showed no difference. The interaction showed a difference $(p<0.05)$ among the means. Tubers of Tela stored in traditional yam barn recorded significantly, the highest numbers of sprouted tubers $(93.33 \%)$ against the least $(53.33 \%)$, seen. Pona stored using open sided store and traditional barn. Without any pre-storage treatment, it was difficult for sprouting to be controlled or minimized at storage. Mozie (1984) reported that, high rate of ventilation reduces the growth rate of vines in stored tubers. However, the result of the study showed sprouting was extremely high, especially with count in traditional yam barn, of which Tela recorded the highest number of sprouted tubers (93.33\%). This was significantly different from Pona, which on average, recorded the least number of sprout under the same storage. It is possible that, the tubers of Pona cultivar could have a long dormancy period. Knoth (1993) reported that the duration of natural dormancy fluctuate according to the variety of yam between $4-18$ weeks.

\subsubsection{Decay}

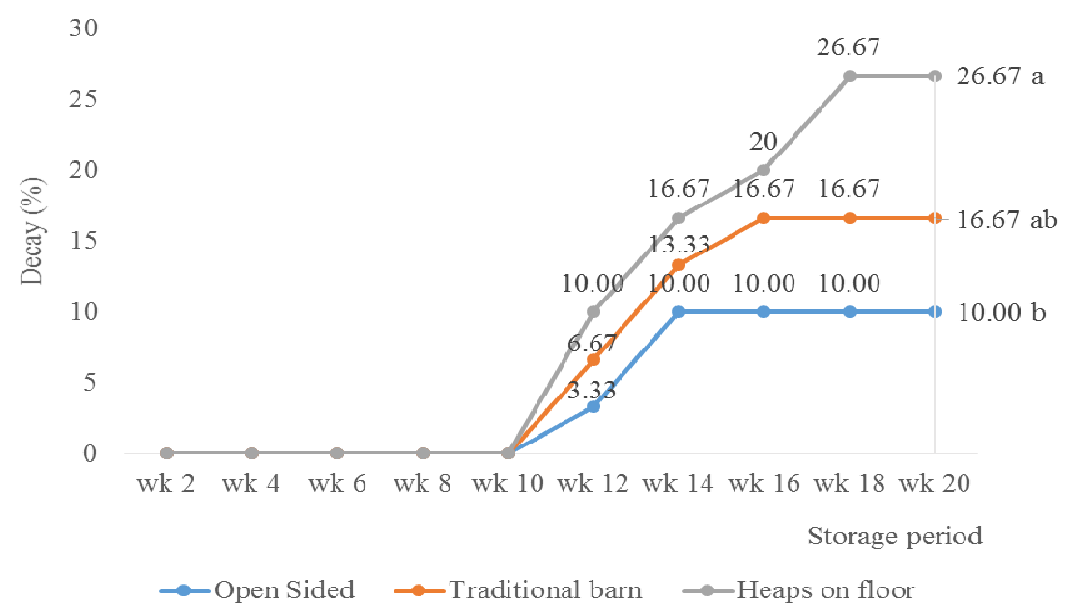

Figure 10. Effect of storage methods on the decay

In the present study, none of the cultivars of the white yam showed any resistence to rot. However, a relatively high incidence of rot was recorded among the Pona in particular, than Tela which was non-significant as compared to cultivar Tela. The three storage methods adopted for the experiment performed equally and suppressed the incidence of decay for 77 days (10 wks). From the 12th week onwards, rot was recorded. The open sided storage method achieved the best results with the least percentage of decay $(10 \%)$ recorded. Heap method of storage had the highest level of decayed tubers $(26.67 \%)$ and was significantly different $(\mathrm{p}<0.05)$ from decay incidence in open sided method. However, traditional yam barn did statistically equal to the earlier two. No significant interaction effect $(\mathrm{p}<0.05)$ was seen between cultivar and the storage methods

Decay was very high in tubers heaped on floor $(26.67 \%)$ as a result of direct contact to either soil or leaves materials on the floor. Presence of rot pathogen in soil or on the leaves material on the storage area serves as a source that initiated decay. Poor air circulation within the heaped yam aid in the build-up of heat and increase humidity as a result of respiration. Hence induces spores germination and growth of pathogens 
Open sided storage method did best as it recorded the least level of rot (10\%). This storage allows in enough ventilation and circulation of air and reduces heat build-up and high humidity level. Decay is one of the main indicators of loss which often occur at transit and storage. It mainly occurs through injuries to a produce which normally gives room for wound pathogen organisms to invade the tissues and hence, cause rot. Amusa et al. (2003) attributed such wounds to encourage insect damages, nematodes attack and ultimately poor handling before, during and after harvest. Yam normally stored best in a cool, well-ventilated storage devoid from excessive high temperature and high relative humidity.

\subsection{Proximate Analysis}

This part of the results gives an account on the effect of the storage methods on the nutritional composition of the two cultivars of white yam selected for the study. The analysis was done just before and after the storage experiment. The nutritional composition analysed comprises of the ash, carbohydrates, fat, fibre, moisture and protein content of the White yam cultivar Pona and Tela.

Table 4. Cultivar effect on the nutritional composition of white yam cultivars before and after the experiment

\begin{tabular}{|c|c|c|c|c|c|c|c|c|c|c|c|c|}
\hline \multirow{2}{*}{ Cultivar } & \multicolumn{2}{|l|}{ Fat } & \multicolumn{2}{|l|}{ Fibre } & \multicolumn{2}{|l|}{ Protein } & \multicolumn{2}{|l|}{ Ash } & \multicolumn{2}{|c|}{ Carbohydrate } & \multicolumn{2}{|c|}{ Moisture } \\
\hline & before & After & Before & After & Before & after & before & after & before & after & before & After \\
\hline Pona & $1.00 \mathrm{~b}$ & $0.98 \mathrm{a}$ & $2.18 \mathrm{~b}$ & $2.07 \mathrm{a}$ & $5.30 \mathrm{a}$ & $5.23 \mathrm{a}$ & $2.17 \mathrm{a}$ & $1.91 \mathrm{a}$ & $91.87 \mathrm{a}$ & $89.17 \mathrm{~b}$ & $69.34 \mathrm{a}$ & $67.24 \mathrm{a}$ \\
\hline Tela & $1.17 \mathrm{a}$ & $1.06 \mathrm{a}$ & $2.33 \mathrm{a}$ & $2.40 \mathrm{a}$ & $5.06 \mathrm{~b}$ & $5.01 \mathrm{~b}$ & $1.83 \mathrm{a}$ & $1.82 \mathrm{a}$ & $91.72 \mathrm{a}$ & $89.38 \mathrm{a}$ & $58.81 \mathrm{~b}$ & $56.64 \mathrm{~b}$ \\
\hline Lsd (0.01) & 0.02 & 0.09 & 0.02 & 0.3 & 0.02 & 0.01 & 1.07 & 0.36 & 0.71 & 0.02 & 0.03 & 0.02 \\
\hline $\mathrm{CV}$ & 1.54 & 6.21 & 0.65 & 10.86 & 0.31 & 0.15 & 35.74 & 12.94 & 0.52 & 0.02 & 0.03 & 0.02 \\
\hline
\end{tabular}

Table 5. Effect of storage methods on the nutritional composition of white yam cultivars before and after the experiment

\begin{tabular}{|c|c|c|c|c|c|c|c|c|c|c|c|c|}
\hline \multirow{2}{*}{ Storage } & \multicolumn{2}{|l|}{ Fat } & \multicolumn{2}{|l|}{ Fibre } & \multicolumn{2}{|l|}{ Protein } & \multicolumn{2}{|l|}{ Ash } & \multicolumn{2}{|c|}{ Carbohydrate } & \multicolumn{2}{|c|}{ Moisture } \\
\hline & before & After & Before & After & Before & after & before & after & before & After & before & After \\
\hline Open Sided & $1.00 \mathrm{~b}$ & $0.98 \mathrm{~b}$ & $3.30 \mathrm{a}$ & $3.07 \mathrm{a}$ & $5.19 \mathrm{a}$ & $5.15 \mathrm{a}$ & 1.75 & $1.85 \mathrm{ab}$ & $91.73 \mathrm{ab}$ & $90.68 \mathrm{a}$ & $67.41 \mathrm{a}$ & $65.94 \mathrm{a}$ \\
\hline Trad barn & $1.00 \mathrm{~b}$ & $0.98 \mathrm{~b}$ & $1.53 \mathrm{c}$ & $1.61 \mathrm{~b}$ & $5.19 \mathrm{a}$ & $5.12 \mathrm{~b}$ & $1.50 \mathrm{a}$ & $1.58 \mathrm{~b}$ & $92.32 \mathrm{a}$ & $89.21 \mathrm{~b}$ & 61.56 & $58.12 \mathrm{c}$ \\
\hline Heaps & $1.25 \mathrm{a}$ & $1.11 \mathrm{a}$ & $1.95 \mathrm{~b}$ & $2.03 \mathrm{~b}$ & $5.17 \mathrm{a}$ & $5.11 \mathrm{~b}$ & $2.75 \mathrm{a}$ & $2.17 \mathrm{a}$ & $91.34 \mathrm{~b}$ & $87.93 \mathrm{c}$ & $63.26 \mathrm{~b}$ & $61.76 \mathrm{~b}$ \\
\hline Lsd (0.01) & 0.03 & 0.17 & 0.03 & 0.44 & 0.03 & 0.01 & 1.31 & 0.44 & 0.87 & 0.03 & 0.03 & 0.03 \\
\hline $\mathrm{CV}$ & 1.54 & 6.21 & 0.65 & 10.86 & 0.31 & 0.15 & 35.74 & 12.94 & 0.52 & 0.02 & 0.03 & 0.02 \\
\hline
\end{tabular}

Table 6. Interaction effect of cultivar $\times$ storage methods on the nutritional composition of white yam cultivars before and after the experiment

\begin{tabular}{|c|c|c|c|c|c|c|c|c|c|c|c|c|}
\hline \multirow{2}{*}{ Interactions } & \multicolumn{2}{|l|}{ Fat } & \multicolumn{2}{|l|}{ Fibre } & \multicolumn{2}{|c|}{ Protein } & \multicolumn{2}{|l|}{ Ash } & \multicolumn{2}{|c|}{ Carbohydrate } & \multicolumn{2}{|c|}{ Moisture } \\
\hline & Before & After & before & After & before & after & before & after & Before & after & before & after \\
\hline Pona *Open Sided & $1.00 \mathrm{~b}$ & $0.98 \mathrm{~b}$ & $3.08 \mathrm{~b}$ & $2.54 \mathrm{~b}$ & $5.69 \mathrm{a}$ & $5.64 \mathrm{~b}$ & $1.50 \mathrm{~b}$ & $1.61 \mathrm{~b}$ & $91.81 \mathrm{ab}$ & $89.82 \mathrm{~b}$ & $73.46 \mathrm{a}$ & $71.37 \mathrm{a}$ \\
\hline $\begin{array}{l}\text { Pona } * \text { Traditional } \\
\text { barn }\end{array}$ & $1.00 \mathrm{~b}$ & $0.97 \mathrm{~b}$ & $1.53 \mathrm{~d}$ & $1.60 \mathrm{c}$ & $4.64 \mathrm{~d}$ & $4.55 \mathrm{f}$ & $1.50 \mathrm{~b}$ & $1.58 \mathrm{~b}$ & $92.86 \mathrm{a}$ & $89.63 \mathrm{c}$ & $66.34 \mathrm{c}$ & $63.55 \mathrm{c}$ \\
\hline $\begin{array}{l}\text { Pona *Heaps on } \\
\text { floor }\end{array}$ & $1.00 \mathrm{~b}$ & $0.98 \mathrm{~b}$ & $1.94 \mathrm{c}$ & $2.07 \mathrm{bc}$ & $5.56 \mathrm{~b}$ & $5.51 \mathrm{c}$ & $3.50 \mathrm{a}$ & $2.55 \mathrm{a}$ & $90.94 \mathrm{~b}$ & $88.05 \mathrm{e}$ & $68.23 \mathrm{~b}$ & $66.80 \mathrm{~b}$ \\
\hline Tela *Open Sided & $1.00 \mathrm{~b}$ & $0.98 \mathrm{~b}$ & $3.52 \mathrm{a}$ & $3.60 \mathrm{a}$ & $4.68 \mathrm{~d}$ & $4.65 \mathrm{e}$ & $2.00 \mathrm{ab}$ & $2.09 \mathrm{ab}$ & $91.65 \mathrm{ab}$ & $91.54 \mathrm{a}$ & $61.37 \mathrm{~d}$ & $60.50 \mathrm{~d}$ \\
\hline $\begin{array}{l}\text { Tela *Traditional } \\
\text { barn }\end{array}$ & $1.00 \mathrm{~b}$ & $0.98 \mathrm{~b}$ & $1.52 \mathrm{~d}$ & $1.62 \mathrm{c}$ & $5.73 \mathrm{a}$ & $5.68 \mathrm{a}$ & $1.50 \mathrm{~b}$ & $1.58 \mathrm{~b}$ & $91.77 \mathrm{ab}$ & $88.78 \mathrm{~d}$ & $56.78 \mathrm{f}$ & $52.68 \mathrm{f}$ \\
\hline $\begin{array}{l}\text { Tela *Heaps on } \\
\text { floor }\end{array}$ & $1.50 \mathrm{a}$ & $1.23 \mathrm{a}$ & $1.96 \mathrm{c}$ & $1.99 \mathrm{bc}$ & $4.77 \mathrm{c}$ & $4.71 \mathrm{~d}$ & $2.00 \mathrm{ab}$ & $1.79 \mathrm{~b}$ & $91.73 \mathrm{ab}$ & $87.81 \mathrm{f}$ & $58.29 \mathrm{e}$ & $56.73 \mathrm{e}$ \\
\hline Lsd (0.01) & 0.04 & 0.16 & 0.04 & 0.62 & 0.04 & 0.02 & 1.85 & 0.62 & 1.23 & 0.04 & 0.05 & 0.04 \\
\hline $\mathrm{CV}$ & 1.54 & 6.21 & 0.65 & 10.86 & 0.31 & 0.15 & 35.74 & 12.94 & 0.52 & 0.02 & 0.03 & 0.02 \\
\hline
\end{tabular}




\subsubsection{Effect of the Three Storage Methods on Nutritional Composition of White Yam}

The results in Tables 4, 5 and 6 showed significant reductions in moisture, fat, protein and carbohydrate except for fibre and ash content of both White yam cultivars after five months of storage with the three storage methods.

The nutritional compositions of the cultivars were in the similar range as reported by Osagie (1992) even after storage. The level of ash increased slightly in both cultivars stored with open sided and traditional yam barn. Likewise, the fibre content of Tela tubers increased when stored with the heaps on floor method and in open sided storage. This reported increase in ash and fibre after storage, was also observed on tubers of White yam variety stored in yam barns with different conditions by Osunde and Orhevba (2009).

It has been reported that, moisture and protein levels in stored yam tubers decreases with time (Ihekeronye \& Ngoddy, 1985). This study also showed a similar result with a decrease in moisture, protein, carbohydrate and fat content in tubers of Pona and Tela of the White yam variety that were stored with the storage methods. The reduction in moisture content and carbohydrate could be due to respiration, transpiration and sprouting of the tubers. These are physiological activity that is promoted by high temperature and high relative humidity of the storage environment (Passam et al., 1978). Passam et al. (1978) further reported that, respiration result in a steady loss of carbohydrate in the form of carbon dioxide and water, while at the same time, transpiratory loss of water occurs.

Research has shown that, traces of tannins which are found in some immature tissues of $D$. rotundata (Osunde \& Orhevba, 2009) form complexes with protein and limit their availability. Hence, it is possible that, the decrease in the protein is due to tannins. The result also reveals that, fat is generally low in yam as shown in Tables 4 and 5 . This could have been due to the result of the high incidence of sprout development and growth, since reserved energy (fat and carbohydrate) and minerals are used for this physiological activity.

Tuber and root crops are rich in carbohydrates (Osunde \& Orhevba, 2009). The tubers had a high level of the carbohydrates within the range reported by Osagie (1992). Generally, carbohydrate decreased slightly after the storage period in the three storage methods of which the levels were significantly different (Table 5). It is supported by Sahore et al. (2007) who report that, carbohydrate content of yam tuber decreases during storage due to conversion of starch to sugar and respiratory losses of sugar as carbon dioxide.

\subsection{Cost Benefit Analysis of the Storage Structures}

The analysis as showed in Table 3.7 proved that open sided storage performed best with expected profit of $\mathrm{GH} \notin 70.00$ regardless of the relatively high cost of GH $\notin 200.00$ incurred during the construction. Heaps on floor broke even whiles traditional barn yielded well with expected profit of GH $\phi 40.00$ per storage of every 30 tubers.

Table 7. Cost-benefit analysis of storage structures for the study

\begin{tabular}{lllll}
\hline & Items/Storage Structure & Open Sided Store & Traditional Barn & Heaps On Floor \\
\hline 1 & Cost of construction & $\mathrm{GH} \phi 100.00$ & $\mathrm{GH} \phi 40.00$ & $\mathrm{GH} \phi 30.00$ \\
2 & Initial cost of tubers (30 per method) & $\mathrm{GH} \phi 90.00$ & $\mathrm{GH} \phi 90.00$ & $\mathrm{GH} \phi 90.00$ \\
3 & Time spent during inspection and data collection & $5 \mathrm{hrs}$ & $15 \mathrm{hrs}$ & $10 \mathrm{hrs}$ \\
4 & Cost of labour per time spent & $\mathrm{GH} \phi 10.00$ & $\mathrm{GH} \phi 30.00$ & $\mathrm{GH} \phi 20.00$ \\
5 & Losses due to decay and pest damage & 3 Tubers & 10 Tubers & 16 Tubers \\
6 & Wholesome tubers remaining at end of storage & 27 Tubers & 20 Tubers & 14 Tubers \\
7 & Income from sales of remaining tubers & $\mathrm{GH} \phi 270.00$ & $\mathrm{GH} \phi 200.00$ & $\mathrm{GH} \phi 140.00$ \\
$*$ & Total Cost & $\mathrm{GHc} 200.00$ & $\mathrm{GH} \phi 160.00$ & $\mathrm{GH} \phi 140.00$ \\
$* *$ & Total Income & $\mathrm{GH} \phi 270.00$ & $\mathrm{GH} \phi 200.00$ & $\mathrm{GH} \phi 140.00$ \\
$* * *$ & Expected Benefit & $\mathrm{GH} \phi 70.00$ & $\mathrm{GH} \phi 40.00$ & $\mathrm{GH} \phi 00.00$ \\
\hline
\end{tabular}

\section{Conclusion}

The study showed sprouting as the major cause of postharvest losses and could be controlled with a high rate of ventilation or airflow which reduced the growth rate of vine in stored tubers. Pona tend to have a longer dormancy period than Tela cultivar. The traditional yam barn could not be seen as the best for storing Tela as $93 \%$ of the 
tubers got sprouted. The open sided performed quite well in minimizing sprouting of the stored tubers. Levels of decay among the cultivars were significantly equal. However, the open sided storage method did best in minimizing decay. No significant difference was recorded among the stored tubers with the various storage methods in terms of weight loss. Pona in general retained significantly, a higher weight than Tela.

The outcome of the study on pests/rodents attack revealed that, Tela cultivar is resistant to pests attack when stored with the three storage methods. Pona was only not attacked when stored with the open sided storage method. Hence, the open sided storage helped prevent pests/rodents attack.

There was a reduction in the nutritional composition of the two cultivars during the storage period. However, there were exceptions. The ash content of both cultivars increased slightly when stored with open sided and traditional yam barn. Tubers of Tela that were heaped on the floor at the end of the storage, recorded slight increase of Fibre.

\section{Recommendation}

Based on the result of the study, open sided storage should be considered by producers of yams for storing their harvested tubers due to the facts that, it performed well in minimizing nutrient lost, weight loss and decay to considerable level and prevented pests/rodents attack as well as had a higher expected profit or benefit of GH $\$ 70.00$ per storage of every 30 tubers. Areas considered for storage should be well ventilated if sprouting and decay are to be prevented and minimized.

\section{Acknowledgement}

The authors are grateful to everyone who has played a role in conducting this research: those who monitored and collected the data, those analysed the data and those who reviewed the manuscript. Their individual contributions are immensely appreciated. Special thanks also go to the publisher for providing time and space to publish this article to the benefit of the public.

\section{References}

Amusa, N. A., Adegbite, A. A., Muhammed, S., \& Baiyewu, R. A. (2003). Yam diseases and their management in Nigeria. African Journal of Biotechnology, 2(12), 497- 502.

FAO (Food and Agricultural Organisation). (1998). FAO Annual Report. Food and Agriculture Organisation Production Year Book. FAO Rome.

FAO (Food and Agricultural Organisation). (2005). FAO Annual Report. Food and Agriculture Organisation Production Year Book. Food and Agricultural Organisation of the United Nations, Rome.

Igbeka, J. C. (1985). Storage practices for yam in Nigeria (pp. 55-58). Agriculture Mechanization in Asia, Africa and Latin America.

Ihekeronye, A. I., \& Ngoddy, P. O. (1985). Integrated food science and technology for the tropics (pp. 266-282 and 366-368). London: McMillan Publishers Ltd.

Ikediobi, C. O., \& Oti, E. (1983). Some biochemical changes associated with post-harvest storage of white yam (Discorearotundata) tubers. J. Sci. Food Agric., 34, 1123-1129. http://dx.doi.org/10.1002/jsfa.2740341013

Knoth, J. (1993). Traditional storage of yams and cassava and its improvement. Deutsche Gesellschaftfür Technische Zusammenarbit (GTZ) post- harvest project (pp. 9-43). Germany: Hamburg.

Mozie, O. (1984). Effect of air flow on weight losses and sprouting of white yam tubers stored in the conventional barn. Tropical Root and Tuber Crops News Letter 13 (pp. 32-37).

National Academy of Sciences. (1978). Post-harvest food losses in developing countries. Washington, D.C: U.S. National Academy of Sciences.

Okigbo, R. N., \& Ogbonnaya, U. O. (2006). Antifungal effects of two tropical plant extracts (Ocimumgratissimumand Aframomummelegueta) on post-harvest yam rot. African Journal of Biotechnology, 5(9), 727-731.

Osagie, A. U. (1992). The yam tuber in storage (pp. 11-18). Postharvest Research Unit. Ambik Press.

Osuji, G. O., \& Umezurike, G. M. (1985). The biochemistry of yam tuber deterioration. In G. O. sujied (Eds.), Advances in Yam Research. The Biochemistry and Technology of the yam Tuber. Biochemical Soc.Of Nigeria/Anambra State University of Technology. AI-United Industries \& Shipping Inc. Taiwan Frontline Publishers, Enugu.

Osunde, Z. D., \& Orhevba, B. A. (2009). Effects of storage conditions and storage period on nutritional and other qualities of stored yam (Dioscoreaspp) tubers. AJFAND, 9(2), $678-690$. 
Passam, H. C., Read, S. J., \& Rickard, J. E. (1978).The respiration of yam tubers and its contribution to storage losses. Trop. Agric, 55, 207-214.

Sahore, D. A., Nemlin, G. J., \& Kamenan, A. (2007). Changes in nutritional properties of yam (Dioscoreaspp), green plantain (Musa spp) and cassava (Manihotesculenta) during storage. Food Science and Technology, 47, 81-88.

Serge, T., \& Agbor-Egbe, T. (1996). Biochemical changes occurring during growth and storage of two yam species.International Journal of Food Science and Nutrition, 47, 93-102. http://dx.doi.org/10.3109/09637489609012570

Sp1ittstoesser, W. E., \& Rhodes, A. M. (1973). Protein and amino acid values of some tropical root crops. Illinois Research, 15(4), 6-7.

Undie, A. S., \& Akubue, P. I. (1986). Pharmacological evaluation of Dioscoreadumetorumtuber used in traditional anti-diabetic therapy. J. Ethnopharmacol., 15, 133-14. http://dx.doi.org/10.1016/0378-8741(86)90150-9

\section{Copyrights}

Copyright for this article is retained by the author(s), with first publication rights granted to the journal.

This is an open-access article distributed under the terms and conditions of the Creative Commons Attribution license (http://creativecommons.org/licenses/by/3.0/). 